\title{
THE PERFORMANCE OF UPLAND RICE ESTABLISHED ON ALANG-ALANG DOMINATED AREA AFTER VARIOUS TECHNIQUES OF ALANG-ALANG CONTROL
}

\author{
S. TJITROSEMTIO \\ SEAMEO BIOTROP, P.O. Box 17, Bogor, Indonesia \\ and \\ A. PURWANTO \\ PT. Monagro Kimia, Wisma Kosgoro Jl. Thamrin, \\ llth Floor, Jakarta, Indonesia
}

\begin{abstract}
Pot experiment to investigate the performance of upland rice in a previously alang-alang dominated area was conducted under greenhouse condition at BIOTROP, Bogor, Indonesia from November 1986 to May 1989. The treatments were factorially combined, replicated 5 times and randomized completely. The first factor was alang-alang control consisting of 5 different techniques, i.e. (1) glyphosate applied at $2.2 \mathrm{~kg}$ a.e./ha; (2) imazapyr applied at $1.5 \mathrm{~kg}$ a.e./ha; (3) dalapon applied twice at $7.4+7.4 \mathrm{~kg}$ a.i./ha; (4) slashing followed by soil cultivation; (5) slashing of alang-alang only; while the second factor was nitrogen fertilizer at 4 different levels, i.e. (1) $0 \mathrm{~kg} \mathrm{~N} / \mathrm{ha}$, (2) $60 \mathrm{~kg} \mathrm{~N} / \mathrm{ha}$, (3) $120 \mathrm{~kg} \mathrm{~N} / \mathrm{ha}$ given twice, $60 \mathrm{~kg} \mathrm{~N} / \mathrm{ha}$ at planting time and $60 \mathrm{~kg}$ $\mathrm{N} / \mathrm{ha}$ at $38 \mathrm{dap}$, (4) $180 \mathrm{~kg} \mathrm{~N} / \mathrm{ha}$ given twice, $90 \mathrm{~kg} \mathrm{~N} / \mathrm{ha}$ at planting and $90 \mathrm{~kg} \mathrm{~N} / \mathrm{ha}$ at 38 dap.

Plant height $(\mathrm{cm})$, tiller number/pot, productive tiller $(\%)$, panicle length $(\mathrm{cm})$, spikelets/panicle, empty spikelet (\%), weight 1000 grains (g) and grain yield (ton/ha) were observed.

Upland rice grown with zero tillage technique using glyphosate (2.2 $\mathrm{kg}$ a.i./ha) or dalapon (14.8 $\mathrm{kg}$ a.i./ha) performed as good as or even better than manual cultivation. Imazapyr at $1.5 \mathrm{~kg}$ a.e./ha was phytotoxic to rice planted 1 month after spraying. The application of $\mathrm{N}$ fertilizer lower than $60 \mathrm{~kg} \mathrm{~N} / \mathrm{ha}$ was not sufficient, but more than $60 \mathrm{~kg} \mathrm{~N} / \mathrm{ha}$ was too high; it stimulated the production of too many tillers, with high percentage of unproductive tillers and empty grains.
\end{abstract}

\section{INTRODUCTION}

Areas under alang-alang (Imperata cylindrica (L.) Beauv.) have recently been utilized for transmigration schemes in Indonesia. The transmigrants from Java and Bali used to cultivate their land before planting upland rice. This practice, however, is very tedious, especially on areas dominated by alang-alang. They are usually able to cultivate only $0.4-0.7$ ha of land manually in this alang-alang dominated area. 
The area under alang-alang is known to be infertile, producing a very low rice yield, insufficient to support the transmigrant's family. It forces them to find additional income, and when the area is close to the forest, they join the group of illegal loggers.

It is imperative to find ways to raise the transmigrant's income to improve their condition. In this context pot experiments were carried out under greenhouse condition to investigate the growth and yield of upland rice in alang-alang dominated areas.

\section{MATERIAL AND METHODS}

Pot experiments were conducted under greenhouse condition at BIOTROP, Bogor, Indonesia from November 1986 to May 1989 to investigate the performance of upland rice grown in a previously alang-alang dominated area established by various techniques at different levels of nitrogen fertilizer.

The alang-alang plants were first established in plastic pots of $20 \mathrm{~cm}$ diameter and 21 $\mathrm{cm}$ height by 5 single-node cuttings/pot for approximately 9 months. For the experiment, 100 pots were utilized. The treatments were factorially combined, replicated $5 \mathrm{x}$ and randomized completely. The first factor was alang-alang control consisting of 5 different techniques, i.e. (1) glyphosate applied at $2.2 \mathrm{~kg}$ a.e./ha; (2) imazapyr applied at $1.5 \mathrm{~kg}$ a.e./ha; (3) dalapon applied twice at $7.4+7.4 \mathrm{~kg}$ a.i./ha; (4) slashing followed by soil cultivation; (5) slashing of alang-alang only; while the second factor was nitrogen fertilizer at 4 different levels, i.e., (1) $0 \mathrm{~kg} \mathrm{~N} / \mathrm{ha}$, (2) $60 \mathrm{~kg} \mathrm{~N} / \mathrm{ha}$, (3) $120 \mathrm{~kg} \mathrm{~N} / \mathrm{ha}$ given twice, $60 \mathrm{~kg} \mathrm{~N} / \mathrm{ha}$ at planting time and $60 \mathrm{~kg} \mathrm{~N} / \mathrm{ha}$ at 38 days after planting, (4) $180 \mathrm{~kg}$ $\mathrm{N} / \mathrm{ha}$ given twice, $90 \mathrm{~kg} \mathrm{~N} / \mathrm{ha}$ at planting and $90 \mathrm{~kg} \mathrm{~N} / \mathrm{ha}$ at 38 days after planting.

Dalapon was sprayed twice at $7.4 \mathrm{~kg}$ a.i./ha each time at intervals of 3 weeks; the other herbicide treatments were done on the same days as the second spraying of dalapon, while slashing and cultivation treatments were carried out on the same day of seed planting. The sprayings were carried out using CP20 at high pressure with yellow nozzle calibrated to deliver an equivalent amount of 600 1/ha.

Upland rice (Oryza sativa c.v. Sentanu) seeds were selected for uniformity and planted one month after the last herbicide spraying, by dibbling 5 seeds/pot at about 2 $\mathrm{cm}$ deep. The plants were later thinned to 3 plants/pot.

The basal fertilizer consisting of $\mathrm{KC} 1$ and Triplesuper-phosphate (TSP) at $60 \mathrm{~kg} \mathrm{~K}_{2} \mathrm{O} / \mathrm{ha}$ and $60 \mathrm{~kg} \mathrm{P} \mathrm{P}_{2} \mathrm{O}_{5} /$ ha, respectively, were given to all pots by dibbling about $5 \mathrm{~cm}$ deep at a distance of $5 \mathrm{~cm}$ from the rice hill. The nitrogen fertilizer in the form of urea was also given in the same manner. 
During the experiment, the soil was kept moist and plants were prevented from pests by spraying with SEVIN 855 and from pathogens by spraying with Dithane M-45. The data collected were plant height at harvest time, number of tillers, number of panicles, length of panicle, number of spikelets/panicle, percentage of empty spikelets, the yield of grain/pot at 14\% moisture content, weight of 1000 grains and yield/ha equivalent.

The data were analysed statistically using F-test and the means were compared with DMRT.

\section{RESULTS AND DISCUSSION}

Upland rice plants grown on pots previously treated with imazapyr at $1.5 \mathrm{~kg}$ a.e./ha were killed. It seems that $1.5 \mathrm{~kg}$ a.e./ha of imazapyr even 1 month after application was still too toxic for upland rice in this pot condition. Similar results were also reported by Tjitrosemito \& Tentamia (1986) with soybean; but it was contrary to the results of field experiments on soybean reported by Tjitrosemito \& Suwinarno (1988), where application of imazapyr at $2.0 \mathrm{~kg}$ a.e./ha to alang-alang fields when planted with soybean 1 month later showed no symptoms of phyto-toxicity. It is important, therefore, to study further the behaviour of imazapyr molecules in the soil and to specify what conditions may increase or decrease its availability to plants to become toxic.

The performance of upland rice is summarized in Tables 1 and 2.

Table 1 . The performance of upland rice established in pots previously occupied by alang-alang after various control techniques

\begin{tabular}{llllll}
\hline Variables & \multicolumn{5}{l}{ Rice establishment after alang-alang control } \\
\cline { 2 - 6 } & $\begin{array}{l}\text { glyphosate }+ \\
\text { zero tillage }\end{array}$ & $\begin{array}{l}\text { dalapon }+ \\
\text { zero tillage }\end{array}$ & $\begin{array}{l}\text { imazapyr }+ \\
\text { zero tillage }\end{array}$ & soil cultivation & $\begin{array}{l}\text { slashed }+ \\
\text { zero tillage }\end{array}$ \\
\hline Plant height (cm) & $85.2 \mathrm{c}$ & $76.9 \mathrm{~b}$ & $0.0 \mathrm{a}$ & $78.1 \mathrm{~b}$ & $69.7 \mathrm{~b}$ \\
Tiller number/pot & $5.5 \mathrm{c}$ & $4.9 \mathrm{~b}$ & $0.0 \mathrm{a}$ & $5.6 \mathrm{c}$ & $4.9 \mathrm{~b}$ \\
Productive tiller (\%) & $76.4 \mathrm{c}$ & $69.4 \mathrm{be}$ & $0.0 \mathrm{a}$ & $67.8 \mathrm{be}$ & $63.3 \mathrm{~b}$ \\
Panicle length (cm) & $19.1 \mathrm{c}$ & $18.8 \mathrm{c}$ & $0.0 \mathrm{a}$ & $17.0 \mathrm{be}$ & $16.0 \mathrm{~b}$ \\
Spikelets/Panicle & $76.5 \mathrm{~d}$ & $65.3 \mathrm{c}$ & $0.0 \mathrm{a}$ & $61.8 \mathrm{c}$ & $55.4 \mathrm{~b}$ \\
Empty spikelet (\%) & $18.7 \mathrm{~b}$ & $18.6 \mathrm{~b}$ & $0.0 \mathrm{a}$ & $16.6 \mathrm{~b}$ & $16.6 \mathrm{~b}$ \\
Weight 1000 grain (g) & $23.6 \mathrm{~b}$ & $22.9 \mathrm{~b}$ & $0.0 \mathrm{a}$ & $23.0 \mathrm{~b}$ & $23.2 \mathrm{~b}$ \\
Grain yield (ton/ha) & $0.81 \mathrm{~d}$ & $0.58 \mathrm{c}$ & $0.0 \mathrm{a}$ & $0.67 \mathrm{~cd}$ & $0.39 \mathrm{~b}$ \\
\hline
\end{tabular}

NB: Numbers in a column followed by the same letter do not differ significantly at $5 \%$ level 
The performance of upland rice established - S. Tjitrosemlto \& A. Purwanto

Table 2. The effect of $\mathrm{N}$-fertilizer on the performance of upland rice established on land previously dominated by alang-alang

\begin{tabular}{llcll}
\hline Variables & \multicolumn{4}{c}{ Rate of nitrogen fertilizer (kg N/ha) } \\
\cline { 2 - 5 } & 0 & 60 & 120 & 180 \\
\hline Plant height (cm) & $38.5 \mathrm{a}$ & $53.0 \mathrm{~b}$ & $57.2 \mathrm{~b}$ & $58.0 \mathrm{~b}$ \\
Tiller number/pot & $3.5 \mathrm{a}$ & $4.3 \mathrm{~b}$ & $6.5 \mathrm{c}$ & $6.6 \mathrm{c}$ \\
Productive tiller (\%) & $51.4 \mathrm{a}$ & $55.8 \mathrm{~b}$ & $50.8 \mathrm{a}$ & $48.5 \mathrm{a}$ \\
Panicle length (cm) & $9.7 \mathrm{a}$ & $12.3 \mathrm{~b}$ & $13.0 \mathrm{bc}$ & $13.5 \mathrm{c}$ \\
Spikelets/Panicle & $33.1 \mathrm{a}$ & $64.6 \mathrm{~b}$ & $79.5 \mathrm{c}$ & $81.7 \mathrm{c}$ \\
Empty spikelet (\%) & $13.3 \mathrm{~b}$ & $9.6 \mathrm{a}$ & $10.9 \mathrm{a}$ & $10.7 \mathrm{a}$ \\
Weight 1000 grain (g) & $14.3 \mathrm{a}$ & $15.3 \mathrm{c}$ & $14.4 \mathrm{ab}$ & $14.7 \mathrm{bc}$ \\
Grain yield (ton/ha) & $0.16 \mathrm{a}$ & $0.44 \mathrm{~b}$ & $0.57 \mathrm{bc}$ & $0.65 \mathrm{c}$ \\
\hline
\end{tabular}

This local upland rice variety produces only a small number of tillers. Its performance was quite well when established by zero tillage after alang-alang had been cleared using glyphosate at (2.2 kg a.e./ha). It produced 0.81 ton/ha of grain which was as good as that produced when the rice planted after alang-alang was slashed followed by manual soil cultivation. Under dalapon treatment it also showed quite a good yield i.e. $0.58 \mathrm{ton} / \mathrm{ha}$ which was not different from that under manual cultivation. When alang-alang was only slashed before dibbling the seed, the rice performed badly. It produced only 0.39 ton/ha equivalent. This was expected because it had to compete against regrowth of alang- alang from rhizomes.

The tillering was somehow very limited under dalapon treatment. There were only 4.9 tillers/pot which was the same as that under slashing, while under glyphosate it was 5.5 tillers/pot. Under glyphosate treatment, this upland rice also showed the highest percentage of productive tillering $(76 \%)$ and the highest number of spikelets/ panicle. It was not surprising to see that the performance of this upland rice with grain yield of 0.81 ton/ha equivalent was the best under glyphosate treatment in this experimental condition.

The effect of nitrogen fertilizer is shown in Table 2. The application of nitrogen fertilizer (60-180 kg N/ha) increased the performance of upland rice. When unfertilized, rice grew short $(38.5 \mathrm{~cm})$ with a small number of tillers, a small part of which became productive. The panicle was also short with a few spikelets and the panicle had a high percentage of empty spikelets. Morever, the grain was light, therefore, the total grain yield was the lowest among the treatments. It is clear that $\mathrm{N}$-fertilizer is badly needed for this rice production.

The application of $60-180 \mathrm{~kg}$ N/ha increased the height and the tiller number' considerably ( $\mathrm{P}<0.01)$; however not all of these increased tillers developed into productive tillers. When this upland rice was fertilized with 120 and $180 \mathrm{~kg} \mathrm{~N} / \mathrm{ha}$, 
apparently too many tillers were produced to develop further into productive tillers. In fact, under $180 \mathrm{~kg} \mathrm{~N} / \mathrm{ha}$, less than $50 \%$ of the tillers produced developed into productive ones, which is worse than rice not treated with fertilizers. Nitrogen fertilizer application at $60 \mathrm{~kg} \mathrm{~N} / \mathrm{ha}$ increased the tiller number and the proportion of tillers developing into productive ones. N-fertilizer rate at $60 \mathrm{~kg} \mathrm{~N} /$ ha is probably the appropriate rate.

Nitrogen fertilizer application increased the number of panicles. Treatments with 120 and $180 \mathrm{~kg} \mathrm{~N} /$ ha increased the spikelet number/panicles more than double, i.e. 79.5 and 81.7 respectively. But, again, this increase was too much to fill up the spikelet which gave lighter grain as assessed by the weight of 1000 grains. Nitrogen fertilizer application at $60 \mathrm{~kg} \mathrm{~N} / \mathrm{ha}$ showed the heaviest grain among the treatments, which supports further the conclusion that the appropriate $\mathrm{N}$-fertilizer application is $60 \mathrm{~kg}$ $\mathrm{N} / \mathrm{ha}$ in this condition.

With the available results, it is obvious that food crops can actually be established in alang-alang dominated area using zero tillage technique, provided that alang-alang is controlled with appropriate herbicides and an appropriate rate of fertilizer is applied.

\section{REFERENCES}

TITROSEMITO, S. and TENTAMIA. 1986. The growth performance of soybean under the influence of herbicide residue. BIOTROP Internal Report. , and D. SUWINARNO. 1988. The performance of soybean (c.v. Americana) established by zero tillage technique in Imperata field controlled by herbicides. BIOTROPIA 2: 12-17. 